\title{
Effect of Global Fertility and Cultural Transition on Population Health: A Test of Competing Perspectives
}

\author{
Jengher Chen \\ Department of Sociology, Fu-Jen University, Taiwan \\ Email: djc434@yahoo.com.tw
}

Received 12 August 2015; accepted 18 June 2016; published 21 June 2016

Copyright (C) 2016 by author and Scientific Research Publishing Inc.

This work is licensed under the Creative Commons Attribution International License (CC BY). http://creativecommons.org/licenses/by/4.0/

cC) (i) Open Access

\begin{abstract}
In this study, a crucial test of competing perspectives on structural determinants of population health has been conducted using the latest available data. These competing perspectives include income inequality thesis on income inequality as an unfavorable condition for population health, world polity theory on the role of international nongovernmental organizations as a favorable condition for population health, and importantly, a newly-formulated demographic transition thesis on how demographic transition as re-conceptualized as global fertility and cultural transition in creating favorable conditions for promoting population health. A panel analysis using random effects modeling and cross-tabulation for 65 less-developed countries over the period 1990-2010 strongly confirms the robust impact of global fertility and cultural transition on all indicators and an index of favorable conditions for population health and subsequent outcomes of population health, even controlling for the favorable condition effect of international nongovernmental organizations and the unfavorable condition effect of income inequality. Along with the process of the demographic transition, the index of favorable conditions for population health can be further applied to population health efforts and effectiveness evaluation (PHEEE) for less developed countries to gauge and predict health-related outcomes. Theoretical, empirical, and policy implications are further discussed.
\end{abstract}

\section{Keywords}

Favorable Conditions for Population Health, Demographic Transition, Income Inequality, World Polity

\section{Introduction}

Although there are multiple determinants of health, for the past decades many studies using income inequality 
thesis have investigated the relationship between income inequality and population health with rather inconsistent, discrepant, and controversial findings reported (Babones, 2008; Beckfield, 2004; Biggs et al., 2010; Judge, Mulligan, \& Benzeval, 1998; Lynch \& Smith, 2000; Lynch et al., 2004; Mackenbach, 2002; Mellor \& Milyo, 2001; Ram, 2006; Pop, Ingen, \& Oorschot, 2012; Tausch, 2012; Wimberley, 1990). Since income inequality represents one of the unfavorable conditions for population health, this study provides an alternative view on how favorable conditions for population health as created by the demographic transition are conducive to the development of population health. Latest research has documented the influence of the demographic transition as a global process in shaping modern society and social economic change (Dyson, 2001, 2011; Murphy, 2011; Reher, 2004, 2011), and a full theorizing of favorable conditions for population health can be extended for approaching a demographic thesis of human well-being. Following Caldwell et al. (2001b), it seems that the research on social determinants of health (SDH) needs to take into consideration the influence of the distal structural forces (like economic development, techno-economic heritage, and economic dependency), the intervening mechanisms of the demographic transition (Dyson, 2001a), the unfavorable conditions of income inequality on health (Pop et al., 2012), as well as the neglected favorable conditions for population health or the role of the international nongovernmental organizations as approached in this study. Conceptually, these favorable conditions for population health might include health manpower prevalence, health innovations prevalence, health living prevalence, and health knowledge prevalence for development of healthier societies. Ultimately, a full theorizing model combining distal structural forces, the intervening mechanism of demographic transition, and favorable conditions for population health, holding constant the effects of income inequality and international nongovernmental organizations, provides a crucial test for approaching the competing perspectives on population health.

Most of the previous work on population health has focused on the structural determinants and constraints of income inequality in a stratified society, but failed to address the probable (wo)man-made efforts and human agency for improving the conditions for population health during the demographic transition process. This study addresses this gap in the literature by arguing that given the structural constraints of social, cultural, economic, and demographic forces, human agency does play a role in improving favorable conditions or changing unfavorable conditions for population health accompanying the demographic transition process.

In the following section, the long research tradition using income inequality thesis for approaching the association between income inequality and population health will be examined first, followed by a theorizing of how favorable conditions for population health can be created during the demographic transition process. The distal structural forces underlying the demographic transition, income inequality, and diffusion of international nongovernmental organizations will be further addressed. This further theoretical consideration will include world polity theory in theorizing the diffusion of international nongovernmental organizations as an alternative favorable condition for population health. A full model with distal structural forces and proximate determinants of demographic transition will then be proposed with income inequality and international nongovernmental organizations taken as controls for empirical test.

\section{Income Inequality as an Unfavorable Condition for Population Health}

For more than three decades since the early work of Rodgers (1979), the association between income inequality and population health has been broadly researched and seems to form a particular research tradition. Nevertheless, the findings as have been reported are quite discrepant and inconsistent (Mellor \& Milyo, 2001; Beckfield, 2004; Pop, Ingen, \& Oorschot, 2012). As has been estimated about half of the studies supported the income inequality thesis, while the other half failed to find a general and full support (see Wilkinson \& Pickett, 2006 for a review). An examination of the theoretical and research efforts on income inequality thesis of population health provides a preliminary account of the problems faced.

First, earlier theoretical arguments for justifying how and why income inequality affects population health include Wilkinson (1992)'s neo-Durkheimian approach, Davey (1996)'s Materialist argument, and Kawachi, Kennedy, \& Wilkinson (1999)'s relative deprivation thesis. A review of these arguments shows that the underlying levels of the theorizing range from macro level relating income inequality to social disintegration and unhealthy societies (Wilkinson, 1992), to meso level focusing on the underinvestment in physical, human and cultural capital such as medical services, education, and cultural activities (Davey, 1996), and the more micro level pointing to the effect of relative deprivation on psychological stress and ill health (Kawachi, Kennedy, \& Wilkinson, 1999). Prior research efforts based on these arguments for relating income inequality to population 
health have been failed due to their theoretical insufficiencies in tracing back structural roots to social change and development theorizing, including core theoretical concepts from modernization theory, ecological-evolutionary theory, and dependency/world system theories (see Crenshaw, 1992; Nielsen \& Anderson, 1995; Alderson \& Nielsen, 1999). Specifically, economic development is expected to exert an inverted U-shaped effect on income inequality, while techno-economic heritage is expected to negatively influence income inequality. According to the dependency/world system perspectives, economic dependency tends to positively impact income inequality, which engenders poor health outcomes (Wimberley, 1990; Tausch, 2012). As can be expected, potential and probable problems of model misspecification and spurious explanation seem inevitable to have plagued the prior research efforts.

Second, as has been documented empirically, given an inverted-U shaped relationship between economic development and income inequality, income inequality is expected to exert most harmful effect on health outcomes during the intermediate level of economic development (see also Muller, 1995 on democracy). In addition, the inverted U-shaped effect of economic development could also be re-presented in the similar inverted Ushaped effects of education and democracy developments on income inequality (Simpson, 1990), which have also been neglected in prior approaches. Moreover, further theory on inequality has pointed to a most serious form of inequality, consolidated parameter, i.e., inequality based on nominal parameters (see Blau, 1977; Messner, 1989), as sketched in macro-structural theory and to be measured by economic discrimination to offer a better account of population health than simple income inequality. Third, in terms of policy implication, prior research using income inequality thesis seemed to neglect the consideration of a full model and generated discrepant and inconsistent findings, as a result, policy efforts based on these findings are dubious and controversial.

Finally and more importantly, if income inequality can be treated as an unfavorable condition for population health, other possible unfavorable conditions such as violence, crime, anti-social behavior, and environmental degradation, could also be theorized for a full account of poor health outcomes. Nevertheless, in light of the latest development of a demographic transition thesis on human development, a further theoretical extension of how those favorable conditions can be created during the demographic transition process could contribute to and forge an alternative understanding of population health outcomes never addressed before.

\section{Demographic Transition and Favorable Conditions for Population Health}

How does demographic transition create favorable conditions for population health? Following the latest works highlighting the importance of the demographic transition as a determinant of subsequent social, economic, and demographic developments (Dyson, 2011; Murphy, 2011; Reher, 2011), the current theoretical extension can be linked to some heuristic theorizing for re-conceptualizing demographic transition as global fertility and cultural transition (Reher, 2004; Chen, 2012; see also Caldwell, 1993). This theorizing highlights the essence of the demographic transition to imply global fertility transition, global societal forms transition, and global communication and diffusion of information and ideas for global cultural transition. An important hypothesis derived and has been supported empirically is the higher the level of the demographic transition in terms of global fertility and cultural transition, the higher the level of human well-being, and the effect seems to be stronger following the latter stages of the transition. A theorizing for linking demographic transition and favorable conditions for population health can be made as follows (see Table 1 ).

First, the stages of the demographic transition, i.e., the pre-transitional phase, transitional phase, post-transitional phase, and second demographic transition phase, coincide roughly the societal forms transition from traditional society, transitional society, to modern society and second modern society (Dyson, 2001). This coincidence is not random by systematic in that during the pre-transitional phase, the most crucial issue is how to cope with a situation of relative higher level of mortality rates. In the classic theory of the epidemiologic transition as proposed by Omran (1971), all populations experienced a shift in the major causes of illness and disease following a progressing from higher to lower mortality levels. The first era called the "age of pestilence and famine" (p. 516), usually featured by higher, varied, and fluctuating mortality rates and a low and variable average life expectancy at birth between 20 and 40 years. In this early transition of health, unfavorable conditions for population health due to lower level of health manpower prevalence and health living prevalence as reflected in lower level of physicians relative to population size and malnutrition prevalence characterize the traditional society. However, (wo)man-made efforts and human agency for creating favorable conditions for population health can come from a good governance from the efforts of the governments as well as change agents of civil society such as intra- and inter-national nongovernmental organizations (Shircliff \& Shandra, 2011; see also Hall \& Lamont, 2009). 
Table 1. A heuristic framework for linking demographic transition re-conceptualized as global fertility and cultural transition and population health.

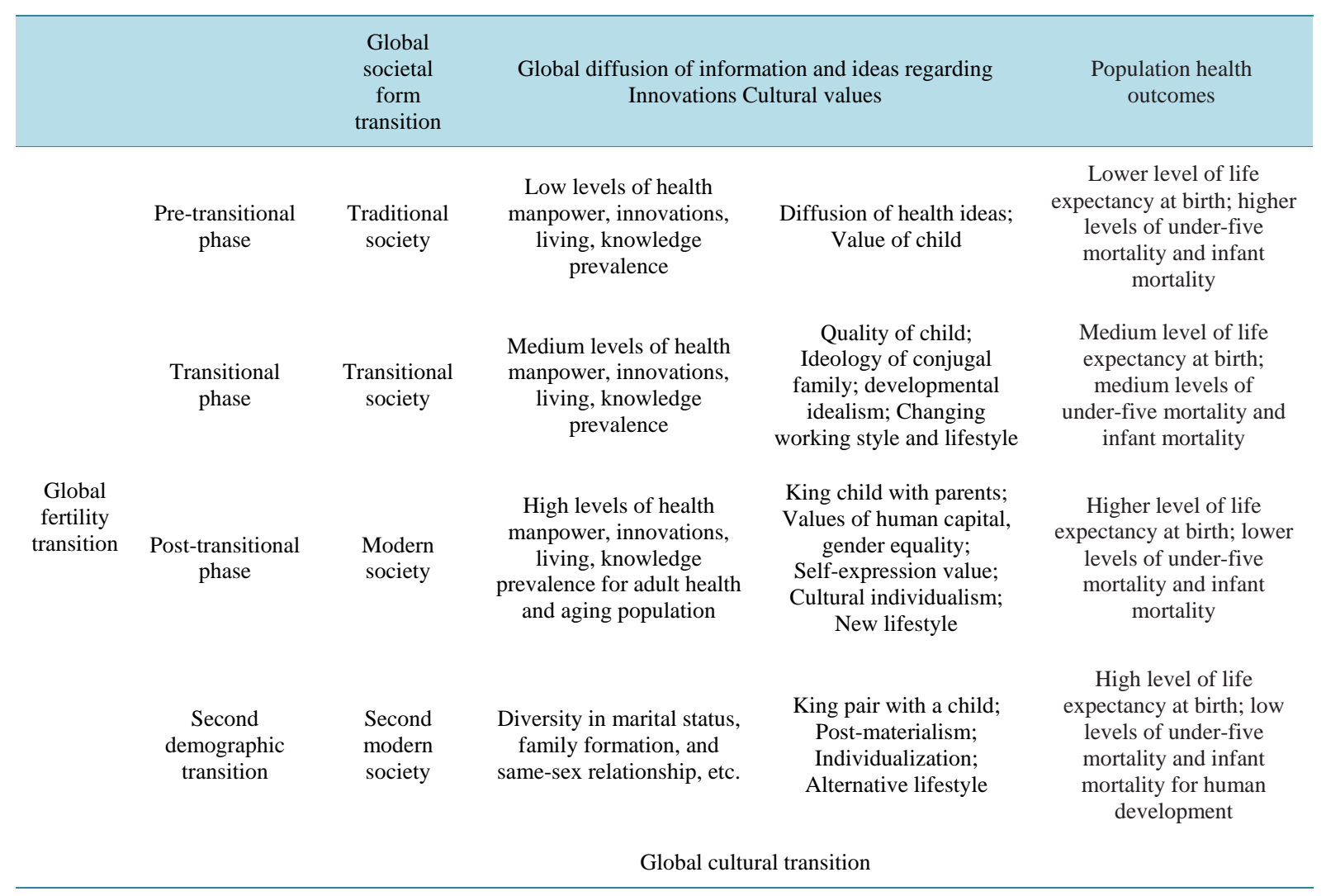

During the transition phase in the "age of receding pandemics", mortality declines steadily with average life expectancy at birth rises from 30 to about 50 years (Omran, 1971: pp. 516-517), yet fertility usually remains high due to support of cultural norms for more children. As sustained population growth begins, (wo)man-made efforts and human agency to challenge traditional norms for higher fertility behavior result in a reduction of fertility levels. During this transition moment, population pressure is usually treated as an unfavorable condition for both economic growth and population health, while certain level of health innovations prevalence in terms of contraceptive prevalence and family planning program efforts foster favorable conditions for promoting population health. In the post-transitional phase, as has been usually observed into the "age of degenerative and manmade diseases", the average life expectancy at birth rises until it exceeds 50 years, and cancers, cardiovascular diseases, accidents constitute the major causes of death (Omran, 1971: pp. 517-518). In this post-transitional modern society, (wo)man-made efforts and human agency for later transition of health as well as more health innovations prevalence for adults health and aging population constitute another favorable conditions for population health.

Second, the stages of the demographic transition also concur with the levels of global diffusion of information and ideas for global cultural transition. In the pre-transitional phase, traditional values and habits of health as well as value of child and large family are unfavorable conditions for population health. By contrast, (wo)manmade and human agency for global communication and diffusion of information, ideas, and cultural values regarding importance of health transition and prevention of communicable diseases are favorable conditions for improving population health. During the transition phase, global diffusion of information and ideas regarding quality of child, ideology of conjugal family, values of universality, achievement orientation, functional specificity, and developmental idealism generate another favorable condition for population health. In the post-transitional phase, further global communication and diffusion of information and ideas for king child with parents, values of human capital and gender equality, self-expression value, and cultural individualism provide solid bases for satisfying physical and psychological needs, and thus promoting by far the most favorable conditions for population health. 
Following the long continuing process of the demographic transition, global diffusion of information and ideas regarding innovations and cultural values enrich the existing material and schematic structures, accompanying (wo)man-made efforts and human agency, create favorable conditions for population health and general human well-being. Latest development of a variant of structure-agency theory, i.e., theory of conjunctural action (Johnson-Hanks et al., 2006), delineates how human agency reflects to both material and schematic structures, which also organize social action by inculcating social actors with intuitions, habits, inclinations and influencing the conjunctures, or configurations of exigencies that social actors might face at specific times. The resolution of conjunctures remakes structure either by reinforcing or transforming the original structures. During the demographic transition process, different phases of the transition are supposed to face different conjunctures, both favorable as well as unfavorable conditions have to be construed and evaluated thoughtfully for (wo)man-made efforts and human agency to adopt actions for change (see also CSDH, 2008). In this regard, a demographic transition thesis on favorable conditions for population health implies a combined structure-agency approach for understanding its influences on promoting general population health.

To sum up, by combining a unique structure-agency approach for theorizing the association between demographic transition and favorable conditions for population health, a derived hypothesis is that net of other effects, demographic transition in terms of global fertility and cultural transition is expected to positively affect favorable conditions for population health, as embodied in manifest indictors of physicians per 1000 people, contraceptive prevalence, (mal)nutrition prevalence, and female to male enrollment. In other words, the higher the level of global fertility and cultural transition, the higher the level of favorable population health conditions, either in terms of indicators or an index construction.

\section{Demographic Transition, Favorable Population Health Conditions, and the Millennium Development Goals}

The Millennium Development Goals as set out in the Millennium Declaration to be reached can be examined and evaluated by the stages of the demographic transition and favorable conditions for population health for less developed countries. First, demographic transition has been linked to the economic development in a more comprehensive and balanced way (Crenshaw \& Ameen, 1997; Reher, 2011). In the early pre-transition phase, unfavorable conditions for population health include higher levels of mortality and fertility rates and burgeoning youth dependency, which also hamper economic development. During the transition phase, a surge of population growth resulted from a decline in mortality and a lag decline in fertility fosters an unfavorable condition for population health. In these earlier phases, higher mortality, higher fertility, youth dependency, and population growth are all conducive to lower economic performance, lower level of health living prevalence, and continuing poverty and hunger in less-developed countries (Hardin, 1993; Myers \& Simon, 1994; Adams, 1994). It is not until the latter phases of the transition can favorable conditions for population health be created by rapid labor force growth, due to the cohort ages and more and more adult population taking their economic roles for economic growth. In the post-transition phase, lower fertility accompanying active male and especially female working populations are contributing to rather favorable conditions for population health, while the aging of the populations with growing burden of welfare expenditures evolves as an unfavorable condition for general population health (Reher, 2011).

Second, the long continuing process of the demographic transition can also be linked directly to health knowledge prevalence through education development and gender equality (Caldwell, 1993), the two most prominent favorable conditions for population health. In the pre-transitional phase, the adverse influences of higher mortality and fertility rates and higher level of youth dependency not only impact economic development but also education development. Consequently, the efforts for prevalence of primary education for both boys and girls are thus retarded due to the male-dominance power structure as well as resistance to global diffusion of value for gender equality in most traditional societies. During transition phase, population begins to grow as a result of mortality decline and fertility persistence, this creates favorable conditions for promoting ideas of birth control through education system (London, 1992) and change agents such as family planning program. In terms of health knowledge prevalence, the adoption and prevalence of contraceptive innovations and ideas engender favorable conditions for population health by empowering women and promoting female's autonomy and gender equality. These favorable conditions for population health are also the preludes for further rising of urbanization (Dyson, 2001) by paving the way for geographic mobility. In the post-transition phase, as usually characterized by lower level of fertility and higher level of female labor force participation, fosters favorable conditions for 
population health through expansion of education system providing vocational skills for both males and females and altering position of women in the society. The aging of population is also conducive to education development by supporting more elderly reentering colleges to pursue higher degrees, which generates favorable conditions for democracy development (Dyson, 2011).

Third, following the classical thesis of epidemiologic transition by Omran (1971), epidemiologic transition has generally paralleled the demographic transition, in addition, due to the higher susceptibility of children and females in reproductive age to infectious and deficiency diseases, the genuine improvements in survivorship accompanying the recession of pandemics are peculiarly beneficial to these two groups. Therefore, a direct derived hypothesis is that demographic transition in terms of global fertility and cultural transition exerts direct influence on both levels of child mortality and maternal mortality. In this regard both global fertility transition and global diffusion of information and ideas for innovations and cultural values are crucial for the reduction of pandemics. Although demographic transition is also expected to create a favorable condition for population health, the latter effect on both child and maternal mortality rates is expected to be weaker and indirect. On the other aspect, the favorable conditions created by the demographic transition are expected to affect killer diseases in a more direct way, this is owing to fact that these killer diseases such as HIV prevalence are less direct respondent to an early shift in pandemics pattern. Overall, due to the long and continuing process of the demographic transition, the influence of the demographic transition in terms of global fertility and cultural transition on epidemiologic transition as measured by the log ratios of communicable to non-communicable diseases, or communicable diseases to injuries (Salomon \& Murray, 2002) will be expected to be less direct and weaker, in contrast to the favorable conditions for population health in terms of health manpower prevalence and health living prevalence, given that physicians per 1000 people and (mal)nutrition prevalence are believed to be more relevant and proximate to the epidemiologic transition.

Finally, in light of the correspondence between demographic transition and the Millennium Development Goals, the higher the level of the demographic transition in terms of global fertility and cultural transition, the higher the level of the Millennium development goals is expected to be reached. Favorable conditions for population health as created by the demographic transition are also conducive to environmental sustainability and global partnership for development. These favorable conditions resulted from a new socio-demographic and socio-ecological equilibrium in post-transitional phase of the transition, in contrast to the unfavorable conditions as exemplified in pre-transitional phase with threats to the environmental resources and the lives of over million slum dwellers due to higher levels of fertility and mortality. Unquestionably, a good governance of the demographic transition process fosters favorable conditions for global partnership for development since either epidemiologic transition from communicable to non-communicable diseases or global diffusion of family planning program efforts cannot be separated from the global participation of different levels of governments as well as international nongovernmental organizations (Shircliff \& Shandra, 2011). Generally, in addition to the positive influence of the demographic transition, a good governance effort for shaping favorable conditions for population health are crucial in affecting environmental sustainability and enforcing global partnership for development, while poor and unfavorable conditions for population health not only lead to environmental degradation but also subsequent lower level of global partnership and participation for development.

\section{The Underlying Distal Structural Forces as Favorable and Unfavorable Distal Conditions for Population Health}

For a full model testing of a demographic transition thesis on population health, a further theorizing of the demographic transition and the resultant favorable conditions for population health needs to trace back their longterm structural roots, which constitute distal macro forces for influencing subsequent social and demographic development. A note on how these structural roots are linked to demographic transition and favorable conditions for population health can be further addressed. Modernization perspective focuses on the development of an industrial society, its variants include industrialism, convergence theory, diffusionism, evolutionism, sequential model of development and culturalism of structural functionalism (Moore, 1966; Parsons, 1966). Proponents in modernization perspective stress the driving force of economic development for accounting for infant mortality decline and later reduction in fertility. By re-conceptualizing demographic transition as global fertility and cultural transition, economic development is expected to exert positive influences on level of global fertility and cultural transition as well as level of favorable conditions for population health. 
By contrast, ecological-evolutionary perspective stresses the importance of techno-economic heritage and social carrying capacity from pre-industrial society for subsequent trajectories of development (Lenski \& Lenski, 1982; Lenski \& Nolan, 1984), which are expected to foster positive impact on level of global fertility and cultural transition and favorable conditions for population health. In addition to the two endogenous intra-national forces for change and development, an exogenous inter-national force resulted from economic dependency and global capitalist development has also been well theorized in dependency/world system perspectives, which consist of classical Marxism, imperialism, Latin American dependency school, and world system theory (Shannon, 1989). Following the neo-Marxist thesis of long term harmful effect of economic dependency, economic dependency in terms of investment dependence and trade dependence is expected to negatively influence the level of global fertility and cultural transition and create unfavorable conditions for population health, due to the underdevelopment and distortion development effects. Importantly, a comprehensive understanding of the structural determinants of social-demographic change needs to take into account all these three distal macro forces for a full model test, or at least be treated as possible control variables.

\section{Alternative Favorable Conditions for Population Health: World Polity Perspective}

The foregoing conceptualization of global fertility and cultural transition implicates global communication and diffusion of information and ideas regarding cultural values and innovations. This gives a clue for further linkage to world polity theory in addressing favorable conditions for population health. The world polity theory identifies world polity as the primary component of the world society, i.e., a world social system with a cultural framework, which provides actors (including nations, international organizations, and individual) of the world society with cultural norms or directions to dealing with problems faced with general procedures. In this regard, international nongovernmental organizations (INGOs) are the important enactors and carriers of world culture for contributing to the improvements of current situations in less developed countries. Given that diffusion should be examined within institutional context, it is generally believed that "cultural construction of empowered actors carrying ultimate values seems especially favorable for diffusion and actors are assumed to have the capacity to innovate and reform and have the moral duty to do so" (Strang \& Meyer, 1993: p. 503). World polity theory with its unique institutionalist accounts has documented the influences of INGOs on behavior of nations and individuals for social change (Boli \& Thomas, 1997). States with many world-polity ties receive many policy scripts from INGOs to shape and enact state policies in different domains more effectively than do those with fewer ties (Boli \& Thomas, 1997; Meyer et al., 1997). Prior cross-national studies have documented the influences of INGOs in many policy domains such as environmental protection, education, welfare provision, population control, same-sexual relations (Frank, 1997, 1999; Shandra et al., 2011; Strang \& Chang, 1993; Schafer, 1999; Barrett \& Frank, 1999; Frank \& McEneaney, 1999). Accordingly, insofar as INGOs profoundly participate in global communication and diffusion of information and ideas for cultural values and innovations, nations with higher levels of INGOs can be expected to demonstrate higher levels of favorable conditions for population health for the nations and societies.

\section{Methods, Measures and Data}

This study proposes an integrated full model for approaching the long-term distal structural as well as more proximate determinants of favorable conditions for population health. As has been known, in multivariate analysis unobserved heterogeneity and influential cases usually plagued regression analysis, yet it does not apply to a full model with strong theoretical bases and with robust independent variables that are long-standing structural conditions (see Finkel, 1995). Scholarship in social science following the legacy of theory-induced research tradition has stressed the importance of theory in guiding research methods. Accordingly, causal inference can only be based on theoretical account rather than be reduced to any single formula mechanically applied to the observational data. This study will use random effects modeling method to test the demographic transition thesis on favorable conditions for population health and the derived hypotheses from the proposed full model. The focus of the panel analyses will be restricted to the less developed countries where the theoretical and research implications of this study are most relevant as explicated and predicted by the theoretical perspectives.

There has been somewhat discrepancy and controversy regarding the choice of random or fixed effects for panel data analysis. Based on the original statistical grounds the fixed effects model seems to be more favorable 
than random effects model given the considerations of heterogeneity bias and serial correlation (Halaby, 2004). However, a more thoughtful and further account of why random effects model is preferred can be forthrightly addressed. First, for some disciplines in social science like sociology there have been cumulated lots of theoretical perspectives for exhaustively accounting the macro, distal structural forces in shaping modern society. These structural forces include the endogenous forces of either pre-industrial society or industrial society, and exogenous forces of world system, economic dependence, and globalization. Provided all these theoretical bases, frankly speaking, there leaves little room for other unobserved effects to be correlated with the explanatory variables. In this regard, the assumption underlying the fixed effects model that unobserved heterogeneity is stable or fixed over time can be vulnerable. Given that the unobserved effects are unimportant, the random effects estimates are closer to a pooled OLS model than the fixed effects model.

Second, fixed effects model does not allow the effects of structural forces variables that are constant over time for a given country to be estimated, consequently, the estimation of these structural effects is rendered imprecise in the fixed effects model. These distal structural forces including economic development, economic dependence, and techno-economic heritage are observed time-invariant factors, which have long been treated as given and constant paving the ways for the latter trajectories of development, and can best be estimated by the random effects model rather than be dropped in the fixed effects model. Finally, model specification can only be justified and based on theoretical account rather than any other statistical rationale. To avoid model misspecification a full model should be specified in advance to incorporate most important theoretical variables in the modeling process, these theoretical variables are sometimes structural or institutional time-invariant explanatory variables and should always be included in the random effects model estimation. Academically, no statistical reasons can justify the exclusion of theoretically important variables from the analysis. For cross-national study where the unit of analysis is individual country, country-specific effects are often thought to be unobserved heterogeneity that needs to be corrected. However, where alternative theoretical accounts of structural forces can be given and resulted in large variance explained, country-specific effects are no more than random variation which are trivial, unimportant, and negligible. For any case unobserved effects can be possibly proposed are usually taken as controls included in the model testing to testify the efficiency and consistency of the explanatory variables.

In the following analyses, the direct impact of all distal macro forces on proximate determinants of favorable conditions for population health will be examined first. These proximate determinants include demographic transition as measured by global fertility and cultural transition, world polity account of international nongovernmental organizations, and income inequality derived from the income inequality thesis of population health. In the second stage, the influences of these proximate determinants on indicators and an index of favorable conditions for population will be estimated. Crucially, net of other effects, an index of global fertility and cultural transition is expected to directly, significantly affect indicators and an index of favorable conditions for population health, and impact subsequently to three usual indicators of population health, life expectancy at birth, under-five mortality, and infant mortality. In order to extend the probable long-term effects of economic dependency as well as techno-economic heritage, all distal macro forces around 1967 (the year PEN measure available) should be included for a full model testing and will be demonstrating expected insignificant effects as intermediated by global fertility and cultural transition. Finally, the full model test will be conducted combining world regions to capture region-specific effects and dummy variables for each of the 5-year period, or waves, to examine possible time-specific effects. A full random effect model can be specified as follows:

$$
y_{i t}=\alpha_{o}+\beta_{1} x_{1 i t}+\beta_{2} x_{2 i t}+\beta_{3} x_{3 i t}+\beta_{4} x_{4 i t}+a_{i}+\varepsilon_{i t}
$$

where $\alpha_{o}$ is the mean overall intercept; $x_{1 i t}$ is proximate determinants for country $i$ at time $t ; x_{2 i t}$ is distal structural forces for country $i$ at time $t$; $x_{3 i t}$ is region-specific effects for country $i$ at time $t$; $x_{4 i t}$ is time-specific effects for country $i$ at time $t ; a_{i}$ is the unobserved effect; and $\varepsilon_{i t}$ is error term.

This study is an attempt to test the derived hypothesis that demographic transition positively affects favorable conditions for population health. Because the specific content of the cultural values varies with different phases of the demographic transition, global diffusion of information and ideas imply this complicated global cultural transition. While global communication and diffusion of information, ideas, and knowledge are conducive to global ideational change, by means of interpersonal communication provides the best channel for the global cultural transition. This is in consistent with what has been argued that "the diffusion of successful strategies of childcare and child-bearing was unquestionably a characteristic of all demographic transitions, past and present" 
(Reher, 2004: p. 32). I would argue further that the global diffusion of information and ideas regarding innovations and cultural values for broadening human choice and improving population health in the large characterize the core process of the demographic transition. In this study global cultural transition can be conceptualized as the global diffusion of information flows, and to be measured by telephone mainlines per 1000 people and internet hosts per 1000 people. Both measures have been natural logged to correct for skewed distribution, the data around 1990, 1995, 2000, and 2005 are available in World Development Indicators as published by the World Bank. Following the latest re-conceptualization of the demographic transition as global fertility and cultural transition (Reher, 2004; Chen, 2012; see also Caldwell, 1993), an index of global fertility and cultural transition can be constructed using indicators of fertility, telephone mainlines and internet hosts. Fertility will be measured by total fertility rates which take into account the age structure factor and generally be considered a more refined measure. The data years for total fertility rate are also around 1990, 1995, 2000, and 2005. Data are available in World Development Report published by the World Bank.

Because a factor analysis shows that total fertility, telephone mainlines and internet hosts are highly correlated and loaded on one factor with factor loadings $-0.914,0.963$, and 0.959 , a theorizing of global fertility and cultural transition to characterize the complicated process of the demographic transition can be empirically embodied in a decline of fertility and an uprising of global cultural transition for index construction. Standardized Z telephone mainlines plus standardized $\mathrm{Z}$ internet hosts, and minus standardized $\mathrm{Z}$ total fertility rate (a negative indicator) around the same years can form an index of global fertility and cultural transition (gFACT3). This index taking the whole complicated fertility and cultural transition simultaneously into account is expected to exert most robust influence than a single measure of total fertility rate. By the same token, an index of global cultural transition can also constructed by adding Standardized Z telephone mainlines and standardized Z internet hosts.

Previous studies on prevalence of health care resources and medical care infrastructure seemed to focus solely on some single indicator, e.g., the number of physicians per 1000 in the population (Wimberley, 1990; Shen \& Williamson, 1997a; Sanderson 2010), and failed to note that a comprehensive understanding of multiple favorable conditions for population health constitutes the infrastructure and the prerequisite for health outcomes. By far there is no composite index for gauging population health infrastructure globally, in order to gauge the health infrastructure multiple indicators of favorable conditions for population health for characterizing population health infrastructure can offer a more comprehensive theoretical account. As delineated in earlier theorizing and based on a structure-agency approach, this multiple indicators approach of favorable conditions for population health can foster solid bases for the conceptualization of the health infrastructure and subsequent application in population health efforts and effectiveness evaluation (PHEEE) for less developed countries.

This study represents a first attempt to conceptualizing favorable conditions for population health as health manpower prevalence, health innovations prevalence, health living prevalence, and health knowledge prevalence, which can be measured by such indicators as physicians per 1000 people, contraceptive prevalence, (mal)nutrition prevalence, and female to male enrollment ratio respectively. This preliminary conceptualization and operationalization does not rule out the possibility that there exist other dimensions of favorable conditions for population health, nor do other possible indicators cannot be included in the index construction. A measure of physicians per 1000 people and level of malnutrition prevalence around 1993, 1998, 2003, and 2008 are available in World Development Indicators published by the World Bank. Female to male ratio of secondary school enrollment refers to the number of females in secondary school per 100 males in secondary school, while contraceptive prevalence can be measured by the percentage of married women of childbearing age currently using contraception. These two measures around 1993, 1998, 2003, and 2008 can be collected from World Development Indicators and Demographic Yearbook. A preliminary analysis of these four indicators of favorable conditions for population health shows that all indicators highly correlated and loaded on one factor with rather high factor loadings presented $(0.86,0.903,0.820$, and -0.799 respectively). These four measures can then be converted into $\mathrm{Z}$ score to form an index by adding standardized $\mathrm{Z}$ physicians, standardized $\mathrm{Z}$ contraceptive prevalence and standardized $\mathrm{Z}$ female to male ratio of enrollment, then minus standardized $\mathrm{Z}$ malnutrition prevalence (a negative indicator).

The structural roots for demographic transition and favorable conditions for population health are those distal macro forces which have to be included in a full model testing. These structural forces have been theorized to be exhaustive and constant in affecting latter trajectories of development. In the analysis these distal structural 
forces represent time-invariant variables can only be estimated by random effects model. Note that with strong theoretical bases rather than statistical grounds can the time-invariant influences of these distal structural forces be fully justified. For measure of economic development or economic modernization, real gross domestic product (RGDP) per capita published by Summers \& Heston (1984) will be used to gauge the increased productivity associated with industrialization in 1970 and 1980. Following the previous work, two measures of economic dependency representing the continuing process of dependence will be used together. An earlier measure of transnational corporate penetration (PEN) in 1967 was provided by Bornschier \& Chase-Dunn (1985) to capture the most critical component of the complex process of dependency and core-peripheral relations. Following Firebaugh (1992) the PEN measure should be inversely interpreted due to the denominator effect. The positive significant effect of PEN should be re-interpreted as a negative one, in accordance with the prediction of the dependency/world system thesis. The other measure of the classical dependency, trade as a percentage of G.N.P. in 1965, is available in Taylor \& Jodice's (1983) World Handbook of Political and Social Indicators. This variable has been logged to correct for its skewed distribution.

Social carrying capacity as a result of the techno-economic heritage will be measured by agricultural density in 1960 (Crenshaw, 1992). In consistent with the two economic dependency measures around 1965 and 1967, agricultural density in 1960 will be appropriate for the present study since the function of social carrying capacity as well as economic dependency are supposed to be long run and extensive (Kentor, 1998; Crenshaw, 1992). This variable has been natural logged to correct for skewness, the data can be obtained from World Handbook of Political and Social Indicators as edited by Taylor \& Hudson (1979).

An additional analysis will include a latest measure of income inequality from standardized world income inequality database (SWIID) which provides by far the most comparable Gini indices of gross and net income inequality for the possible largest samples of countries and years (Solt, 2009). The years covered in the analysis are 1990, 1995, 2000, and 2005. Based on insights from theorizing of world polity perspective for favorable conditions for population health, the number of international nongovernmental organizations for 1990, 1995, 2000, and 2005 can be collected from the Yearbook of International Associations. The population data can be obtained from the World Bank to standardize and calculate INGOs per capita for comparison across different nations. Also included in the final analysis is some usual measures of population health outcome, life expectancy at birth, Infant mortality rate, and under-five mortality rate, data for 1995, 2000, 2005, and 2010 can be obtained from Demographic Yearbook published by the United Nations and World Development Indicators by the World Bank ${ }^{1}$.

\section{Findings}

Table 2 presents the influences of distal macro structural forces on proximate determinants of favorable conditions for population health, these proximate determinants cover core measures for world polity theory, income inequality thesis, and the proposed demographic transition thesis. All measures of distal macro forces including economic development, investment dependence, trade dependence, and techno-economic heritage demonstrate theoretically expected effects. Economic development significantly and positively affects INGOs per capital (an indicator of world polity theory) and an index of global fertility and cultural transition (gFACT3) for capturing a continuous conceptualization of demographic transition. The impact of economic development on income inequality supports Kuznets's inverted U-shape thesis, total fertility rate as a crude measure of demographic transition also yields expected positive influence, although a measure of global fertility and cultural transition does not reach significant level (see also Nielsen \& Anderson, 1995), note that INGOs per capita fails to exhibit any significant result (cf. Beckfield, 2003) as expected. In accord with the dependency/world system thesis, economic dependency as measured by investment and trade dependence seems to exert negative and harmful effects on global fertility and cultural transition, note that investment dependence should be interpreted inversely following Firebaugh (1992). The effects of economic dependency on development of international nongovernmental organizations and income inequality are somewhat discrepant and unexpected. Techno-economic heritage as a measure of ecological-evolutionary theory does positively influence global fertility and cultural transition, but

\footnotetext{
${ }^{1}$ According to dependency/world system theories and ecological-evolutionary theory, the influence of economic dependency and techno-economic heritage tends to be long run in nature, thus, the time lag for distal structural forces can be at least twenty years or even longer. Unless specified, the time-lag for proximate determinants is five-year for income inequality, global fertility and cultural transition, and international nongovernmental organizations in 1990, 1995, 2000, and 2005. The data years for outcomes of population health are 1995, 2000, 2005, and 2010, while the intervening effects for indicators of favorable conditions for population health are around 1993, 1998, 2003, and 2008.
} 
yields no impact on development of international nongovernmental organizations and income inequality. Overall, all distal structural forces display rather consistent and expected effects on global fertility and cultural transition, but not other proximate determinants of favorable conditions for population health.

Table 2 also shows an interesting result for both composite indicators of global fertility and cultural transition. Both economic development and techno-economic heritage seem to affect total fertility rate in theoretically expected way, although a rigorous test of the determinants of fertility needs to take more explanatory variables into account. The influences of distal structural forces on global cultural transition deserve some theoretical attention in that all distal structural forces all significantly affect global cultural transition, as expected by the three theoretical perspectives. Total fertility rate exhibits theoretical and expected negatively effect on global cultural transition, note that following world polity thesis the development of international nongovernmental organizations also has some positive but smaller impact on global cultural transition.

Table 2. Random effects model estimates of first and second endogenous variables on distal structural forces.

\begin{tabular}{|c|c|c|c|c|c|c|c|c|}
\hline & (1) & (2) & (3) & (4) & (5) & (6) & (7) & (8) \\
\hline & gFACT3 & $\begin{array}{l}\text { INGOs per } \\
\text { capita (ln) }\end{array}$ & $\begin{array}{l}\text { INGOs per } \\
\text { capita (ln) }\end{array}$ & $\begin{array}{l}\text { Income } \\
\text { inequality }\end{array}$ & $\begin{array}{l}\text { Total } \\
\text { fertility } \\
\text { rate }\end{array}$ & $\begin{array}{l}\text { Global } \\
\text { cultural } \\
\text { transition }\end{array}$ & $\begin{array}{c}\text { Global } \\
\text { cultural } \\
\text { transition }\end{array}$ & $\begin{array}{c}\text { Global } \\
\text { cultural } \\
\text { transition }\end{array}$ \\
\hline \multirow[t]{2}{*}{$\begin{array}{c}\text { Economic } \\
\text { development }\end{array}$} & $0.0015^{* * *}$ & $0.0004^{* * *}$ & $0.0004^{*}$ & $-0.0032^{* *}$ & $-0.0041^{* *}$ & $0.0009^{* * * *}$ & $0.0010^{* * * *}$ & $0.0010^{* * *}$ \\
\hline & $(8.02)$ & (3.79) & $(2.43)$ & $(-2.95)$ & $(-2.83)$ & $(7.44)$ & (7.67) & (7.19) \\
\hline \multirow[t]{2}{*}{$\begin{array}{l}\text { Investment } \\
\text { dependence }\end{array}$} & $0.0001^{* *}$ & $0.0001^{*}$ & 0.0001 & $0.0010^{* *}$ & -0.0004 & $0.0001^{*}$ & $0.0001^{* *}$ & $0.0001^{*}$ \\
\hline & $(2.58)$ & $(2.21)$ & $(1.53)$ & (3.38) & $(-0.73)$ & $(2.47)$ & $(2.71)$ & $(2.30)$ \\
\hline \multirow[t]{2}{*}{ Trade dependence } & $-1.3757^{* * *}$ & $0.5511^{*}$ & $0.7372^{* *}$ & -1.7406 & 5.0265 & $-0.8115^{* *}$ & $-0.9042^{* * *}$ & $-0.9231^{* * *}$ \\
\hline & $(-3.82)$ & (2.33) & (2.98) & $(-0.98)$ & $(1.82)$ & $(-3.32)$ & $(-3.60)$ & $(-3.78)$ \\
\hline \multirow{2}{*}{$\begin{array}{l}\text { Techno-economic } \\
\text { heritage }\end{array}$} & $0.5431^{* * *}$ & -0.0122 & -0.0364 & -0.2387 & $-1.8237^{*}$ & $0.3238^{* * * *}$ & $0.3168^{* * * *}$ & $0.3646^{* * *}$ \\
\hline & $(4.53)$ & $(-0.15)$ & $(-0.42)$ & $(-0.44)$ & $(-1.99)$ & (3.98) & (3.79) & $(4.61)$ \\
\hline \multirow[t]{2}{*}{$\begin{array}{c}\text { Economic } \\
\text { development }^{2}\end{array}$} & & & & $-1.30 \mathrm{e}-06^{\#}$ & & & & \\
\hline & & & & $(-1.68)$ & & & & \\
\hline \multirow[t]{2}{*}{ Total fertility rate } & & & $0.0232^{* * *}$ & $0.0430^{*}$ & & & $-0.0428^{* * *}$ & $-0.0504^{* * *}$ \\
\hline & & & (5.55) & (2.19) & & & $(-11.42)$ & $(-9.16)$ \\
\hline \multirow{2}{*}{$\begin{array}{l}\text { Global cultural } \\
\text { transition }\end{array}$} & & & 0.0989 & & & & & \\
\hline & & & (1.6) & & & & & \\
\hline \multirow{2}{*}{$\begin{array}{l}\text { INGOs per capita } \\
\text { (ln) }\end{array}$} & & & & 0.5414 & & & & $0.2841^{*}$ \\
\hline & & & & $(0.66)$ & & & & (2.51) \\
\hline \multirow[t]{2}{*}{ Income inequality } & & & & & & & & 0.0126 \\
\hline & & & & & & & & $(1.01)$ \\
\hline Constant & -3.1010 & -13.0860 & -13.6063 & 58.1566 & 23.8432 & -2.1729 & -1.6194 & 0.7048 \\
\hline $\mathrm{R}^{2}$ & 0.7070 & 0.3908 & 0.4632 & 0.2800 & 0.0767 & 0.6435 & 0.6992 & 0.6808 \\
\hline N/Observations & $64 / 159$ & $63 / 223$ & $61 / 129$ & $60 / 191$ & $65 / 251$ & $64 / 161$ & $64 / 159$ & $57 / 119$ \\
\hline
\end{tabular}

$t$ statistics in parentheses. ${ }^{\#} p<0.10{ }^{*} p<0.05,{ }^{* *} p<0.01,{ }^{* * *} p<0.001$. 
Table 3 displays the combined effects of distal structural forces and proximate determinants on indicators or an index of favorable conditions for population health and the subsequent outcomes of population health. The most consistent results come from the influence of global fertility and cultural transition (gFACT3), the effects are robust throughout all equations. The impact of international nongovernmental organizations on outcomes of population health, including life expectancy at birth, aged under-five mortality, and infant mortality rate, seems to reveal unexpectedly but rather significant effects. A reversed explanation might be that international nongovernmental organizations seem to be induced into less developed countries with poor population health. All measure of economic development also demonstrate a rather consistent and expected effect on all favorable conditions and outcomes of population health, although the effect are somewhat smaller than that of global fertility and cultural transition. Techno-economic heritage also displays its unique effect on most of the favorable conditions and outcomes of population health as expected by the prediction of ecological-evolutionary theory.

A full model test combining distal structural forces, region-specific effects, and time-specific effects for comparing the relative effects of total fertility rate and global fertility and cultural transition (gFACT3) on indicators and an index of favorable conditions for population health can be displayed in Table 4 to Table $5^{2}$.

Table 3. Random effects model estimates of favorable conditions and outcomes of population health on distal structural forces and proximate determinants.

\begin{tabular}{|c|c|c|c|c|c|c|c|c|}
\hline & (1) & (2) & (3) & (4) & (5) & (6) & (7) & (8) \\
\hline & $\begin{array}{l}\text { Physicians } \\
\text { per } 1000\end{array}$ & $\begin{array}{l}\text { Contraceptive } \\
\text { prevalence }\end{array}$ & $\begin{array}{c}\text { Malnutrition } \\
\text { prevalence }\end{array}$ & $\begin{array}{l}\text { Female to } \\
\text { male } \\
\text { enrollment }\end{array}$ & $\begin{array}{l}\text { Index of } \\
\text { favorable } \\
\text { conditions for } \\
\text { population } \\
\text { health }\end{array}$ & $\begin{array}{l}\text { Life } \\
\text { expectancy } \\
\text { at birth }\end{array}$ & $\begin{array}{l}\text { Aged under } \\
\text { five } \\
\text { mortality rate }\end{array}$ & $\begin{array}{l}\text { Infant } \\
\text { mortality } \\
\text { rate }\end{array}$ \\
\hline \multirow[t]{2}{*}{ gFACT3 } & $0.3028^{* * *}$ & $2.8334^{* * * *}$ & $-2.3344^{* * * *}$ & $2.1992^{* * *}$ & $0.5867^{* * * *}$ & $0.8370^{* * *}$ & $-6.9079^{* * *}$ & $-4.1680^{* * *}$ \\
\hline & (5.09) & $(4.00)$ & $(-4.75)$ & (3.57) & $(4.47)$ & $(4.00)$ & $(-4.38)$ & $(-4.86)$ \\
\hline \multirow[t]{2}{*}{$\begin{array}{l}\text { Income } \\
\text { inequality }\end{array}$} & 0.0156 & -0.2162 & -0.0916 & 0.1652 & $0.0486^{*}$ & -0.0620 & 0.3793 & 0.2081 \\
\hline & $(1.27)$ & $(-1.47)$ & $(-0.91)$ & $(1.22)$ & $(2.14)$ & $(-1.39)$ & (1.08) & (1.10) \\
\hline \multirow[t]{2}{*}{$\begin{array}{l}\text { INGOs per } \\
\text { capita (ln) }\end{array}$} & 0.0091 & -1.1457 & -0.4730 & -0.3555 & $0.5587^{*}$ & $-2.4536^{* * *}$ & $8.2267^{*}$ & $6.1187^{* *}$ \\
\hline & $(0.09)$ & $(-0.76)$ & $(-0.51)$ & $(-0.27)$ & $(2.43)$ & $(-5.06)$ & (2.44) & (3.27) \\
\hline \multirow[t]{2}{*}{$\begin{array}{c}\text { Economic } \\
\text { development }\end{array}$} & $0.0006^{* * *}$ & $0.00136^{* * *}$ & $-0.0041^{* *}$ & $0.0078^{* *}$ & $0.0024^{* *}$ & $0.0067^{* * *}$ & $-0.0251^{* * *}$ & $-0.0156^{* * *}$ \\
\hline & $(4.70)$ & $(4.52)$ & $(-2.67)$ & (2.98) & (6.09) & (6.38) & $(-4.34)$ & $(-4.63)$ \\
\hline \multirow[t]{2}{*}{$\begin{array}{l}\text { Investment } \\
\text { dependence }\end{array}$} & $-4.89 e-0.6$ & -0.0001 & 0.0004 & 0.0014 & -0.0001 & 0.0004 & -0.0015 & -0.0006 \\
\hline & $(-0.11)$ & $(-0.02)$ & $(0.98)$ & (1.89) & $(-0.67)$ & (1.29) & $(-0.86)$ & $(-0.68)$ \\
\hline \multirow[t]{2}{*}{$\begin{array}{c}\text { Trade } \\
\text { dependence }\end{array}$} & -0.4582 & $-9.3388^{*}$ & -3.3779 & -0.0177 & 0.2673 & -2.9651 & 13.7890 & 5.7296 \\
\hline & $(-1.85)$ & $(-1.96)$ & $(-1.50)$ & $(-0.00)$ & $(0.43)$ & $(-1.68)$ & (1.49) & (1.05) \\
\hline \multirow[t]{2}{*}{$\begin{array}{c}\text { Techno-economic } \\
\text { heritage }\end{array}$} & 0.0255 & 2.6765 & 1.0990 & $4.4314^{* *}$ & $0.8506^{* * *}$ & $1.7626^{* *}$ & $-9.6885^{* *}$ & $-5.5800^{* *}$ \\
\hline & $(0.30)$ & (1.69) & (1.29) & $(2.71)$ & (3.65) & (2.93) & $(-3.05)$ & $(-2.99)$ \\
\hline Constant & -0.6979 & 48.1749 & 17.6314 & 36.7964 & -4.3070 & 30.8506 & 180.0255 & 133.0078 \\
\hline $\mathrm{R}^{2}$ & 0.7586 & 0.6427 & 0.6411 & 0.5643 & 0.8846 & 0.5871 & 0.6441 & 0.6287 \\
\hline N/Observations & $52 / 98$ & $50 / 98$ & $51 / 90$ & $52 / 102$ & $40 / 56$ & $57 / 119$ & $57 / 119$ & $57 / 119$ \\
\hline
\end{tabular}

$t$ statistics in parentheses. ${ }^{*} p<0.05,{ }^{* *} p<0.01,{ }^{* * *} p<0.001$.

${ }^{2} \mathrm{An}$ additional analysis using OLS method shows that for five-year lag and ten-year lag, the results of Breusch-Pagan test are:1.79 ( $p=$ $0.1808)$ and $0.00(p=0.9885)$ respectively, indicating no problem of heteroskedasticity in the model. 
Table 4. Random effects model estimates of indicators of favorable conditions for population health on global fertility and cultural transition (gFACT3).

\begin{tabular}{|c|c|c|c|c|c|c|c|c|}
\hline & (1) & (2) & (3) & (4) & (5) & (6) & (7) & (8) \\
\hline & $\begin{array}{c}\text { Physicians per } \\
1000 \text { (ln) }\end{array}$ & $\begin{array}{c}\text { Physicians per } \\
1000 \text { (ln) }\end{array}$ & $\begin{array}{l}\text { Contraceptive } \\
\text { prevalence }\end{array}$ & $\begin{array}{l}\text { Contraceptive } \\
\text { prevalence }\end{array}$ & $\begin{array}{l}\text { Malnutrition } \\
\text { prevalence }\end{array}$ & $\begin{array}{l}\text { Malnutrition } \\
\text { prevalence }\end{array}$ & $\begin{array}{c}\text { Female/male } \\
\text { enrollment }\end{array}$ & $\begin{array}{c}\text { Female/male } \\
\text { enrollment }\end{array}$ \\
\hline \multirow[t]{2}{*}{ Total fertility } & 0.0056 & & -0.0822 & & $0.1591^{*}$ & & -0.1619 & \\
\hline & $(1.00)$ & & $(-1.19)$ & & (2.49) & & $(-0.91)$ & \\
\hline \multirow[t]{2}{*}{ gFАCT3 } & & $0.3448^{* * * *}$ & & $3.5053^{*}$ & & $-2.6860^{* *}$ & & $3.1882^{*}$ \\
\hline & & (3.33) & & (2.12) & & $(-3.01)$ & & $(2.46)$ \\
\hline \multirow[t]{2}{*}{$\begin{array}{l}\text { Income } \\
\text { inequality }\end{array}$} & $0.0207^{*}$ & 0.0027 & -0.0244 & -0.3286 & $-0.2203^{* *}$ & -0.0851 & -0.0459 & 0.0606 \\
\hline & (2.39) & $(0.18)$ & $(-0.19)$ & $(-1.81)$ & $(-2.93)$ & $(-1.01)$ & $(-0.23)$ & $(0.46)$ \\
\hline \multirow[t]{2}{*}{$\begin{array}{l}\text { INGOs per } \\
\text { capita (ln) }\end{array}$} & 0.1073 & -0.1989 & 0.2046 & -1.7242 & $-4.2576^{* *}$ & -1.9542 & -0.1930 & -1.4503 \\
\hline & $(0.71)$ & $(-1.27)$ & $(0.07)$ & $(-0.88)$ & $(-3.28)$ & $(-1.32)$ & $(-0.06)$ & $(-0.55)$ \\
\hline \multirow[t]{2}{*}{$\begin{array}{c}\text { Economic } \\
\text { development }\end{array}$} & $0.0008^{* * *}$ & 0.0003 & 0.0085 & 0.0054 & $-0.0058^{* * *}$ & -0.0032 & 0.0058 & 0.0045 \\
\hline & (5.06) & $(1.49)$ & (1.83) & $(1.41)$ & $(-3.90)$ & $(-1.45)$ & (1.31) & $(1.14)$ \\
\hline \multirow[t]{2}{*}{$\begin{array}{l}\text { Investment } \\
\text { dependence }\end{array}$} & 0.0000 & -0.0000 & -0.0003 & -0.0013 & 0.0004 & $0.0009^{* * *}$ & 0.0008 & 0.0001 \\
\hline & $(0.80)$ & $(-0.13)$ & $(-0.27)$ & $(-1.48)$ & $(0.81)$ & (3.91) & $(0.86)$ & $(0.17)$ \\
\hline \multirow[t]{2}{*}{$\begin{array}{c}\text { Trade } \\
\text { dependence }\end{array}$} & $-0.7322^{* *}$ & -0.0074 & -7.2508 & 3.1245 & 3.4004 & -2.4513 & 1.0546 & 8.9193 \\
\hline & $(-2.71)$ & $(-0.02)$ & $(-1.09)$ & $(0.71)$ & $(1.45)$ & $(-1.11)$ & $(0.13)$ & $(1.48)$ \\
\hline \multirow[t]{2}{*}{$\begin{array}{l}\text { Techno-economic } \\
\text { heritage }\end{array}$} & 0.0673 & -0.0456 & 1.2101 & 0.0948 & -0.7420 & -0.2329 & 3.4936 & 2.9559 \\
\hline & $(0.77)$ & $(-0.37)$ & $(0.56)$ & $(0.05)$ & $(-0.74)$ & $(-0.27)$ & (1.51) & $(1.28)$ \\
\hline \multirow[t]{2}{*}{ Asia } & $1.3356^{* * * *}$ & 0.3659 & $25.7510^{* *}$ & 15.3609 & 3.1194 & $9.9934^{* * *}$ & 10.1056 & 2.2849 \\
\hline & (3.34) & $(0.79)$ & $(2.81)$ & $(1.70)$ & $(0.92)$ & $(4.62)$ & $(1.27)$ & $(0.37)$ \\
\hline \multirow[t]{2}{*}{ South America } & $1.2918^{* * *}$ & $1.0908^{* * *}$ & $29.4051^{* * *}$ & $31.0064^{* * *}$ & -2.2456 & -1.4879 & $20.2291^{* *}$ & $14.2636^{*}$ \\
\hline & $(4.92)$ & (4.67) & (3.62) & $(4.04)$ & $(-1.09)$ & $(-0.69)$ & (2.75) & $(2.21)$ \\
\hline \multirow[t]{2}{*}{ Mideast } & $1.6558^{* *}$ & $1.4193^{* *}$ & $19.9216^{*}$ & 15.0429 & -6.2137 & -3.1537 & 6.3038 & -5.4427 \\
\hline & (2.93) & $(2.61)$ & $(2.01)$ & $(1.40)$ & $(-1.56)$ & $(-1.18)$ & $(0.46)$ & $(-0.50)$ \\
\hline \multirow[t]{2}{*}{1990} & $-0.7691^{*}$ & 0.4184 & -6.7570 & 1.5616 & 3.3498 & -2.0800 & -0.5685 & 6.5251 \\
\hline & $(-2.45)$ & (1.17) & $(-1.85)$ & $(0.38)$ & $(1.03)$ & $(-0.58)$ & $(-0.07)$ & (1.49) \\
\hline \multirow[t]{2}{*}{1995} & -0.4037 & 0.3257 & -4.5337 & 1.2263 & 3.0459 & 2.1434 & 1.4869 & 2.6394 \\
\hline & $(-1.33)$ & $(1.13)$ & $(-1.45)$ & $(0.37)$ & (1.38) & $(0.92)$ & $(0.23)$ & $(0.98)$ \\
\hline \multirow[t]{2}{*}{2000} & -0.0676 & 0.0737 & $-2.9279^{*}$ & -2.2333 & $4.0378^{* * *}$ & $3.2376^{* * * *}$ & -1.2576 & -1.1544 \\
\hline & $(-0.73)$ & $(0.71)$ & $(-2.19)$ & $(-1.58)$ & $(4.76)$ & (3.36) & $(-0.71)$ & $(-0.90)$ \\
\hline Constant & -0.7333 & -3.4507 & 47.0030 & 25.1940 & -24.3291 & 1.1891 & 46.3290 & 15.8048 \\
\hline $\mathrm{R}^{2}$ & 0.7385 & 0.8203 & 0.7385 & 0.8304 & 0.6981 & 0.8025 & 0.5555 & 0.6383 \\
\hline N/Observations & $58 / 160$ & $52 / 98$ & $58 / 160$ & $50 / 98$ & $56 / 142$ & $51 / 90$ & $55 / 155$ & $52 / 102$ \\
\hline
\end{tabular}

$t$ statistics in parentheses. ${ }^{*} p<0.05,{ }^{* *} p<0.01,{ }^{* * *} p<0.001$. 
Table 5. Random effects model estimates of favorable conditions for population health index and life expectancy at birth on global fertility and cultural transition.

\begin{tabular}{|c|c|c|c|c|c|c|}
\hline & (1) & (2) & (3) & (4) & (5) & (6) \\
\hline & $\begin{array}{l}\text { Index of favorable } \\
\text { conditions for } \\
\text { population health }\end{array}$ & $\begin{array}{l}\text { Index of favorable } \\
\text { conditions for } \\
\text { population health }\end{array}$ & $\begin{array}{l}\text { Life expectancy } \\
\text { at birth } \\
\text { (5-year lag) }\end{array}$ & $\begin{array}{l}\text { Life expectancy } \\
\text { at birth } \\
\text { (5-year lag) }\end{array}$ & $\begin{array}{l}\text { Life expectancy } \\
\text { at birth } \\
\text { (10-year lag) }\end{array}$ & $\begin{array}{c}\text { Life expectancy } \\
\text { at birth } \\
\text { (5-year lag) }\end{array}$ \\
\hline \multirow[t]{2}{*}{ Total fertility } & -0.0216 & & $-0.0986^{* * *}$ & & & \\
\hline & $(-1.38)$ & & $(-4.64)$ & & & \\
\hline \multirow[t]{2}{*}{ gFACT3 } & & $0.8854^{* * * *}$ & & $0.5229^{\#}$ & $2.4394^{* * * *}$ & 0.6531 \\
\hline & & $(3.51)$ & & $(1.81)$ & $(4.93)$ & $(1.47)$ \\
\hline $\begin{array}{l}\text { Index of favorable } \\
\text { conditions for } \\
\text { population health }\end{array}$ & & & & & & $\begin{array}{c}0.8997^{* *} \\
(2.78)\end{array}$ \\
\hline \multirow[t]{2}{*}{ Income inequality } & 0.0190 & 0.0306 & $0.0950^{* *}$ & -0.0664 & $-0.2858^{* *}$ & -0.0419 \\
\hline & $(1.20)$ & $(0.63)$ & (2.87) & $(-1.64)$ & $(-2.89)$ & $(-1.11)$ \\
\hline \multirow[t]{2}{*}{$\begin{array}{l}\text { INGOs per } \\
\text { capita (ln) }\end{array}$} & 0.6113 & 0.0052 & 1.2534 & 0.5417 & -0.0900 & $1.2--2$ \\
\hline & (1.49) & $(0.02)$ & $(1.40)$ & (0.69) & $(-0.11)$ & $(1.23)$ \\
\hline \multirow[t]{2}{*}{$\begin{array}{c}\text { Economic } \\
\text { development }\end{array}$} & $0.0016^{*}$ & 0.0013 & $0.0038^{* * *}$ & $0.0039^{* * *}$ & 0.00003 & 0.0020 \\
\hline & $(2.01)$ & $(1.81)$ & $(4.03)$ & $(4.17)$ & $(0.04)$ & $(1.38)$ \\
\hline \multirow[t]{2}{*}{$\begin{array}{l}\text { Investment } \\
\text { dependence }\end{array}$} & 0.0001 & $-0.0002^{*}$ & $4.39 e-06$ & -0.0001 & -0.0002 & -0.0004 \\
\hline & $(0.55)$ & $(-2.17)$ & $(0.01)$ & $(-0.33)$ & $(-0.85)$ & $(-1.41)$ \\
\hline \multirow[t]{2}{*}{ Trade dependence } & -1.6268 & 0.9360 & -2.4545 & -0.9216 & 0.4075 & -1.3018 \\
\hline & $(-1.59)$ & $(1.21)$ & $(-1.33)$ & $(-0.55)$ & $(0.25)$ & $(-0.60)$ \\
\hline \multirow[t]{2}{*}{$\begin{array}{c}\text { Techno-economic } \\
\text { heritage }\end{array}$} & $0.7201^{* *}$ & $0.6145^{*}$ & 0.3570 & 0.5468 & 0.0039 & 0.5180 \\
\hline & $(2.58)$ & $(2.34)$ & $(0.58)$ & $(1.01)$ & $(0.01)$ & $(0.68)$ \\
\hline \multirow[t]{2}{*}{ Asia } & $1.9680^{*}$ & -0.8763 & $12.5687^{* * *}$ & $10.1573^{* * *}$ & $4.9474^{\#}$ & $7.0566^{*}$ \\
\hline & $(2.00)$ & $(-0.93)$ & $(4.46)$ & $(4.02)$ & $(1.86)$ & (2.53) \\
\hline \multirow[t]{2}{*}{ South America } & $3.1312^{* *}$ & 1.5803 & $10.3653^{* * *}$ & $11.2494^{* * *}$ & $9.8338^{* * *}$ & $8.3897^{* * *}$ \\
\hline & $(2.82)$ & $(1.67)$ & $(4.58)$ & $(5.75)$ & $(4.98)$ & $(3.72)$ \\
\hline \multirow[t]{2}{*}{ Mideast } & $3.1475^{*}$ & 1.2393 & $12.4112^{* * *}$ & $8.7070^{* *}$ & $6.4594^{*}$ & $7.1418^{*}$ \\
\hline & (1.99) & $(0.71)$ & (3.96) & (3.02) & (2.33) & $(2.35)$ \\
\hline \multirow[t]{2}{*}{1990} & -0.5975 & & -1.7667 & $-3.5813^{* *}$ & 1.4729 & $-5.2530^{* * *}$ \\
\hline & $(-0.88)$ & & $(-1.38)$ & $(-2.88)$ & (1.12) & $(-5.55)$ \\
\hline \multirow[t]{2}{*}{1995} & -0.2801 & 0.9596 & -1.7267 & $-2.9275^{* *}$ & & $-3.1104^{* *}$ \\
\hline & $(-0.45)$ & $(1.51)$ & $(-1.70)$ & $(-3.39)$ & & $(-2.71)$ \\
\hline \multirow[t]{2}{*}{2000} & $-0.5614^{*}$ & -0.1496 & $-2.4545^{* * *}$ & $-2.0152^{* * *}$ & & $-2.2936^{* * *}$ \\
\hline & $(-2.01)$ & $(-0.49)$ & $(-4.59)$ & $(-4.88)$ & & $(-4.35)$ \\
\hline Constant & 3.0160 & -8.3895 & $70.0739^{* *}$ & $63.8540^{* * *}$ & 75.3158 & $77.1735^{* * *}$ \\
\hline $\mathrm{R}^{2}$ & 0.7681 & 0.9253 & 0.7463 & 0.8078 & 0.8830 & 0.8876 \\
\hline N/Observations & $45 / 86$ & $40 / 56$ & $60 / 191$ & $57 / 119$ & $57 / 63$ & $40 / 56$ \\
\hline
\end{tabular}

$t$ statistics in parentheses. ${ }^{*} p<0.10{ }^{*} p<0.05,{ }^{* *} p<0.01,{ }^{* * *} p<0.001$. 
Importantly, global fertility and cultural transition rather than total fertility rate alone seems to be the most consistent proximate determinant of favorable conditions for population health. By contrast, total fertility rate seems to demonstrate rather insignificant effects on either indicators or an index of favorable conditions for population health. Interestingly, a further full model test for outcomes of population health as shown in Table 5 to Table 6

Table 6. Random effects model estimates of aged under-five mortality rate and infant mortality rate on global fertility and cultural transition (gFACT3).

\begin{tabular}{|c|c|c|c|c|c|c|}
\hline & (1) & (2) & (3) & (4) & (5) & (6) \\
\hline & $\begin{array}{l}\text { Aged under-five } \\
\text { mortality rate }\end{array}$ & $\begin{array}{l}\text { Aged under-five } \\
\text { mortality rate }\end{array}$ & $\begin{array}{l}\text { Aged under-five } \\
\text { mortality rate }\end{array}$ & $\begin{array}{l}\text { Infant mortality } \\
\text { rate }\end{array}$ & $\begin{array}{l}\text { Infant mortality } \\
\text { rate }\end{array}$ & $\begin{array}{l}\text { Infant mortality } \\
\text { rate }\end{array}$ \\
\hline \multirow[t]{2}{*}{ Total fertility } & $1.5294^{* * * *}$ & & & $0.6679^{* * * *}$ & & \\
\hline & $(4.27)$ & & & $(4.61)$ & & \\
\hline \multirow[t]{2}{*}{ gFACT3 } & & $-7.0872^{* * *}$ & -2.0655 & & $-3.4832^{* *}$ & -0.6568 \\
\hline & & $(-3.34)$ & $(-0.58)$ & & $(-2.97)$ & $(-0.33)$ \\
\hline $\begin{array}{l}\text { Index of favorable conditions } \\
\text { for population health }\end{array}$ & & & $\begin{array}{c}-11.3213^{* * *} \\
(-3.50)\end{array}$ & & & $\begin{array}{c}-6.4913^{* *} \\
(-2.67)\end{array}$ \\
\hline \multirow[t]{2}{*}{ Income inequality } & -0.4731 & 0.5801 & 0.1482 & -0.2686 & 0.2499 & 0.0069 \\
\hline & $(-0.96)$ & $(1.82)$ & $(0.12)$ & $(-0.96)$ & $(1.46)$ & $(0.01)$ \\
\hline \multirow[t]{2}{*}{ INGOs per capita (ln) } & -3.2136 & 1.0485 & -0.2688 & -2.9163 & -0.8325 & -1.5580 \\
\hline & $(-0.53)$ & $(0.22)$ & $(-0.04)$ & $(-0.66)$ & $(-0.30)$ & $(-0.20)$ \\
\hline \multirow[t]{2}{*}{ Economic development } & -0.0155 & -0.0111 & 0.0001 & $-0.0107^{*}$ & $-0.0087^{* *}$ & -0.0011 \\
\hline & $(-1.95)$ & $(-1.90)$ & $(0.02)$ & $(-2.17)$ & $(-2.58)$ & $(-0.14)$ \\
\hline \multirow[t]{2}{*}{ Investment dependence } & -0.0008 & 0.0009 & 0.0029 & -0.0003 & 0.0006 & 0.0016 \\
\hline & $(-0.47)$ & $(0.55)$ & $(1.23)$ & $(-0.32)$ & $(0.70)$ & $(1.00)$ \\
\hline \multirow[t]{2}{*}{ Trade dependence } & 8.8289 & -1.5856 & 4.8976 & 6.6485 & -0.0030 & 5.1790 \\
\hline & $(0.76)$ & $(-0.16)$ & $(0.34)$ & $(1.01)$ & $(-0.00)$ & $(0.49)$ \\
\hline \multirow[t]{2}{*}{ Techno-economic heritage } & -3.0660 & -4.0109 & -2.4022 & -2.0841 & -2.5809 & -1.8602 \\
\hline & $(-0.69)$ & $(-1.29)$ & $(-0.43)$ & $(-0.78)$ & $(-1.38)$ & $(-0.49)$ \\
\hline \multirow[t]{2}{*}{ Asia } & $-62.0636^{* * *}$ & $-37.0719^{*}$ & -12.7020 & $-36.2232^{* *}$ & $-23.6439^{* *}$ & -8.6043 \\
\hline & $(-3.55)$ & $(-2.49)$ & $(-0.55)$ & $(-3.34)$ & $(-2.68)$ & $(-0.82)$ \\
\hline \multirow[t]{2}{*}{ South America } & $-51.5831^{* * *}$ & $-51.1657^{* * *}$ & -17.4611 & $-26.7535^{* * *}$ & $-27.3704^{* * *}$ & -9.2096 \\
\hline & $(-5.42)$ & $(-4.50)$ & $(-1.09)$ & $(-3.55)$ & $(-4.03)$ & $(-1.26)$ \\
\hline \multirow[t]{2}{*}{ Mideast } & $-66.0495^{* *}$ & $-35.2056^{*}$ & -12.4419 & $-34.5747^{* *}$ & -18.3010 & -5.5360 \\
\hline & $(-2.88)$ & $(-2.14)$ & $(-0.73)$ & $(-3.11)$ & $(-1.85)$ & $(-0.54)$ \\
\hline \multirow[t]{2}{*}{1990} & -24.6162 & 2.9420 & -- & -3.8132 & 7.2136 & -- \\
\hline & $(-1.72)$ & $(0.32)$ & & $(-0.61)$ & $(1.45)$ & \\
\hline \multirow[t]{2}{*}{1995} & -15.8087 & 6.7659 & 15.5633 & -1.6852 & $7.3675^{*}$ & $12.5204^{*}$ \\
\hline & $(-1.53)$ & $(1.12)$ & $(1.68)$ & $(-0.38)$ & $(2.18)$ & $(2.03)$ \\
\hline \multirow[t]{2}{*}{2000} & $14.7348^{* * *}$ & $12.3177^{* * *}$ & $14.5782^{* *}$ & $8.8632^{* * *}$ & $7.7360^{* * *}$ & $9.1240^{* *}$ \\
\hline & $(4.82)$ & $(4.26)$ & $(2.81)$ & $(4.40)$ & $(4.83)$ & (2.63) \\
\hline Constant & 83.2574 & 102.6531 & 40.2842 & 40.7514 & 54.8327 & 14.7769 \\
\hline $\mathrm{R}^{2}$ & 0.7267 & 0.7906 & 0.8977 & 0.7292 & 0.7812 & 0.8768 \\
\hline N/Observations & $60 / 191$ & $57 / 119$ & $40 / 56$ & $60 / 191$ & $57 / 119$ & $40 / 56$ \\
\hline
\end{tabular}

$t$ statistics in parentheses. ${ }^{*} p<0.05,{ }^{* *} p<0.01,{ }^{* * *} p<0.001$. 
reveals that both total fertility rate and global fertility and cultural transition exhibit rather significant and consistent effects on life expectancy at birth, aged under-five mortality rate, and infant mortality rate. Comparing to a five-year lag specification, a lag of ten years seems most suitable for the effect of global fertility and cultural transition to demonstrate robust effects on life expectancy at birth ${ }^{3}$, the similar effects can also be obtained for life expectancy at birth for male or female (findings not reported). As expected by the income inequality thesis, this ten-year lag effect also applies to an impact of income inequality on life expectancy birth but not for aged under-five mortality rate and infant mortality rate. Specifically, the un-standardized regression coefficients reveal that global fertility and cultural transition exerts expected robust effects on all outcomes of population health as compared to that of total fertility rate. All the influences of global fertility and cultural transition on outcomes of population health seem to be intermediated by an index of favorable conditions for population health, as demonstrated by significant turning to insignificant results for global fertility and cultural transition. Overall, the findings give strong supports for the proposed demographic transition thesis in explaining the favorable conditions and outcomes of population health. This study improves on earlier research efforts based on approaches of primary health care (Walsh \& Warrant, 1979; Wimberley, 1990), which seem to neglect the roles of distal macro forces as well as demographic transition as possible determinants of population health.

Because higher fertility or rapid population growth characterizes only some particular but not all the phases of the demographic transition, this study not only improves on earlier work following neo-Malthusians and human ecology theory in using rapid population growth alone to accounting for economic growth, income inequality, and human well-being (Ahluwalia, 1976; Hardin, 1993; Adams, 1994; Myers \& Simon, 1994; Nielsen \& Anderson, 1995), but also many prior research efforts using fertility decline alone in determining its effects on maternal health, quality of life, social mobility, women employment, marriage market, diversity in marital status, and government expenditures on old age pensions, health expenditures, and human capital expenditures (Murdoch, 1980; Brown, 1987; Dyson, 1989, 2011; Wimberley, 1990; Clark \& Filinson, 1991; McNay, 1995; Wickrama \& Lorenz, 2002; Kwon, 2003; Van Bavel, 2006; Chen, 2009; Lee \& Mason, 2010). The discrepant findings regarding the simple population growth or fertility decline effect can be further reexamined by taking global fertility and cultural transition into a full account. Importantly, all prior research seems to neglect the proximate role of demographic transition to be re-conceptualized as a complex of global fertility and cultural transition in affecting either favorable conditions or outcomes of population health. Also neglected in earlier research is a comprehensive consideration of all distal structural forces, including the exogenous force of economic dependency, and endogenous forces of techno-economic heritage and economic development combined in determining the crucial intervening effect of the demographic transition on population health.

Following a structure-agency approach, favorable conditions for population health implicates (wo)man-made efforts and human agency for improving population health, can be further applied to indicating population health efforts and effectiveness evaluation (PHEEE) for less developed countries. For an instance, by cross-tabulating the two most important determinants of population health using a measure of demographic transition, gFACT3, and an index of favorable conditions for population health, PHEEE, different averages of life expectancy at birth in 2005 can be calculated for 52 less developed countries with their world positions of population health revealed $^{4}$ (see Table 7). The average life expectancy at birth ranges from 51.93 years in low gFACT3 and PHEEE levels, to 64.21 years in medium gFACT3 and PHEEE levels, and 73.05 years in high gFACT3 and PHEEE levels. For countries with medium level of PHEEE, the average life expectancy at birth varies with levels of gFACT3, from 60.25 years to 64.21 years, and 73.65 years, implies that levels of the demographic transition really matter in affecting level of population health. However, upon reaching the high level of the demographic transition, it seems that the (wo)man-made efforts and human agency no longer make significant improvement for life expectancy at birth.

By contrast, for countries in the medium level of the demographic transition, (wo)man-made efforts and human agency can really make some difference for life expectancy at birth from 64.21 years to 69.31 years. The same influence can also be observed for countries in the low level of the demographic transition, (wo)man-made efforts and human agency for favorable conditions can improve population health in terms of life expectancy at birth from 51.93 years to 60.25 years. Following the proposed thesis of favorable conditions created by the

\footnotetext{
${ }^{3}$ A preliminary analysis of Hausman test examining the effects of global fertility and cultural transition, income inequality, and international nongovernmental organizations on life expectancy at birth shows an insignificant test result $(0.80, p=0.3703)$ and accepts the null hypothesis. Results are available upon request.

${ }^{4}$ The countries included in the analysis are roughly representative of all world regions and world system positions: peripheral country 40 , semi-peripheral country 12; Africa 26, Asia 9, Latin America 13, Middle East 4.
} 
Table 7. World Positions of Population Health for 52 Less Developed Countries by Cross-Tabulation of Global Fertility and Cultural Transition (gFACT3) and Population Health Efforts and Effectiveness Evaluation (PHEEE) with Different Average life Expectancy at Birth in 2005.

\begin{tabular}{|c|c|c|c|}
\hline & Low PHEEE & Medium PHEEE & High PHEEE \\
\hline $\begin{array}{l}\text { Low } \\
\text { gFACT3 }\end{array}$ & $\begin{array}{c}\text { Average life expectancy at birth: } 51.93 \\
\text { years } \\
\text { Afghanistan, Benin, Ethiopia, Ghana, } \\
\text { Guinea, Malawi, Mali, Mauritania, } \\
\text { Mozambique, Niger, Nigeria, Rwanda, } \\
\text { Sudan, Tanzania, Togo, Uganda, } \\
\text { Zambia }\end{array}$ & $\begin{array}{c}\text { Average life expectancy at birth: } \\
60.25 \text { years } \\
\text { Bangladesh, Cameroon, Iraq, Lesotho, } \\
\text { Pakistan }\end{array}$ & \\
\hline $\begin{array}{l}\text { Medium } \\
\text { gFACT3 }\end{array}$ & & $\begin{array}{l}\text { Average life expectancy at birth: } \\
\text { 64.21 years } \\
\text { Botswana, Egypt, Guatemala, } \\
\text { Guyana, India, Indonesia, Kenya, } \\
\text { Maldives, Morocco, Philippines, } \\
\text { Sri Lanka, Swaziland }\end{array}$ & $\begin{array}{l}\text { Average life expectancy at birth: } \\
69.31 \text { years } \\
\text { Algeria, Ecuador, El Salvador, Jordan, } \\
\text { Nicaragua, Peru, South Africa }\end{array}$ \\
\hline $\begin{array}{c}\text { High } \\
\text { gFACT3 }\end{array}$ & & $\begin{array}{c}\text { Life expectancy at birth: } 73.65 \text { years } \\
\text { Malaysia }\end{array}$ & $\begin{array}{l}\text { Average life expectancy at birth: } \\
\text { 73.05 years } \\
\text { Chile, Colombia, Dominican R., Iran, } \\
\text { Jamaica, Kuwait, Mexico, } \\
\text { Trinidad/Tobago, Turkey, Venezuela }\end{array}$ \\
\hline
\end{tabular}

demographic transition, no high level of PHEEE, i.e., high level of favorable conditions for population health is to be expected for countries in the low level of the demographic transition, nor is the low level of PHEEE can be witnessed in medium and high levels of the demographic transition. Finally as a contrast, if using economic development and income inequality for cross-tabulation (Table not presented), the result shows that all the less developed countries distributed quite dispersedly with no clear pattern presented for different average life expectancy at birth (chi-square $=2.733, \mathrm{df}=4, p=0.603)^{5}$.

\section{Conclusion and Discussion}

After three decades' research efforts in examining the relationship between income inequality and population health, it is about time to reorient the research problem to a more balanced view of favorable conditions as well as unfavorable conditions for population health. This study represents a very first endeavor in crucially testing competing perspectives of income inequality thesis, world polity theory, and a newly-formulated demographic transition thesis on population health with all the latest available data. A full model test combining regionspecific effects and time-specific effects shows that in contrast to the negligible effects of income inequality and international nongovernmental organizations, a measure of global fertility and cultural transition strongly impact favorable conditions for population health, which subsequently yield robust effects in affecting life expectancy at birth, aged under-five mortality, and infant mortality. Overall, this crucial test confirms the newly-formulated demographic transition thesis on population health, while clearly falsifies the income inequality thesis and world polity theory. The measures of favorable conditions for population health can be further applied to a policy consideration for population health efforts and effectiveness evaluation (PHEEE), which combined with the level of the demographic transition (gFACT3), offer a heuristic device for understanding and predicting the differential distributions of average life expectancy at birth as well as other health outcomes in less developed countries.

Theoretically, in contrast to the structural determinants of the transition by either eco-biologic factors, socioeconomic, political and cultural factors, or medical and public health factors as initially proposed by Omran (1971), following the long continuing process of the demographic transition, global diffusion of information and ideas regarding innovations and cultural values enrich the existing material and schematic structures, accompanying (wo)man-made efforts and human agency, create favorable conditions for population health and general human well-being (see also London and Schneider 2012; Young 2012). As a response to an earlier urge by Omran (1971: p. 536): "Despite the inherent difficulties in attempting to structure a matrix that includes all the complex vital factors of population dynamics, the need to do so is urgent”, this study enriches the income inequality thesis tradition on income inequality and population health by using a structure-agency approach to reo-

\footnotetext{
${ }^{5}$ The cross-tabulation has also been applied to aged under-five mortality and infant mortality rate with similar significant distributions revealed. The results of cross-tabulation using economic development and international nongovernmental organizations also failed to reach meaningful significant pattern of distribution.
} 
rienting theorizing to the influence of demographic transition and alternative favorable conditions for population health, net of the effect of international nongovernmental organizations as postulated by world polity theory. Empirically and importantly, the results show rather robust effects of both demographic transition and favorable conditions for population health in affecting population health outcomes. In contrast to a latest claim on a globalization-oriented perspective on health, inequality, and MNC penetration (Tausch, 2012), MNC penetration does have some expected effects on global fertility and cultural transition, international nongovernmental organizations, and global cultural transition, but no significant effects on either favorable conditions for or outcomes of population health in terms of income inequality embedded within the world system.

By using random effects model analysis this study provides a general and strong support for the proposed thesis that demographic transition not only creates favorable conditions for population health, but also impacts expected health-related outcomes. This thesis can also be further extended to approaching other research issues relating to the demographic transition which have never been explored before, including epidemiologic transition (Salomon \& Murray, 2002), maternal mortality (Shen \& Williamson, 1999), killer diseases (Shircliff \& Shandra, 2011), urbanization (Dyson, 2011), and democracy development (Dyson, 2001).

The research and policy implications for social determinants of health (SDH) are rather profound. First, the current endeavors might be better reoriented the income inequality research tradition to a more balanced view of all possible favorable and unfavorable conditions for addressing SDH. In this regard, future research may try to broaden and deepen the contents as well as measures of both favorable and unfavorable conditions for a comprehensive evaluation of all probable conditions for health-related outcomes. Crucially, the initiative conceptualization of favorable conditions for population health as health manpower, innovations, living, knowledge prevalence to capture health infrastructure globally provides an important step for future theorizing of a full theory of population health. Second, the distal structural forces including endogenous forces of economic development, techno-economic heritage, exogenous forces of economic dependency, as well as the proximate role of demographic transition should be brought into account for their latter trajectories of development of population health. Finally, policy implication points to the classification of individual countries for their world positions of population health as exemplified in the cross-tabulation of the global fertility and cultural transition and population health efforts and effectiveness evaluation.

\section{References}

Adams, J. (1994). Continuing Poverty in the Global Economy: The Impact of Population Growth. In T. R. DeGegori, \& H. R. Rodgers Jr. (Eds.), Poverty Policy in Developing Countries (pp. 173-196). Greenwich, CT: Jai Press.

Ahluwalia, M. S. (1976). Inequality, Poverty and Development. Journal of Development Economics, 3, 307-342. http://dx.doi.org/10.1016/0304-3878(76)90027-4

Alderson, A. S., \& Nielsen, F. (1999). Income Inequality, Development, and Dependence: A Reconsideration. American Sociological Review, 64, 606-631. http://dx.doi.org/10.2307/2657259

Babones, S. J. (2008). Income Inequality and Population Health: Correlation and Causality. Social Science and Medicine, 66, 1614-1626. http://dx.doi.org/10.1016/j.socscimed.2007.12.012

Barrett, D., \& Frank, D. J. (1999). Population Control for National Development: From World Discourse to National Policies. In J. Boli, \& G. M. Thomas (Eds.), Constructing World Culture: International Nongovernmental Organizations since 1875 (pp. 198-221). Stanford, CA: Stanford University Press.

Beckfield, J. (2003). Inequality in the World Polity: The Structure of International Organization. American Sociological Review, 68, 401-424. http://dx.doi.org/10.2307/1519730

Beckfield, J. (2004). Does Income Inequality Harm Health? New Cross-National Evidence. Journal of Health and Social Behavior, 45, 231-248. http://dx.doi.org/10.1177/002214650404500301

Biggs, B., King, L., Basu, S., \& Stuckler, D. (2010). Is Wealthier Always Healthier? The Impact of National Income Level, Inequality, and Poverty on Public Health in Latin America. Social Science and Medicine, 71, 266-273. http://dx.doi.org/10.1016/j.socscimed.2010.04.002

Blau, P. M. (1977). Inequality and Heterogeneity: A Primitive Theory of Social Structure. New York: Free Press.

Boli, J., \& Thomas, G. M. (1997). World Culture in the World Polity: A Century of International Non-Governmental Organization. American Sociological Review, 62, 171-190. http://dx.doi.org/10.2307/2657298

Bornschier, V., \& Chase-Dunn, C. (1985). Transnational Corporations and Underdevelopment. New York: Praeger Press.

Brown, L. R. (1987). Analyzing the Demographic Trap. In: L. R. Brown, E. C. Wolf, \& L. Starke (Eds.), State of the World 
1987 (pp. 20-37). New York: V.V. Norton.

Caldwell, J. C. (1993). Health Transition: The Cultural, Social and Behavioral Determinants of Health in the Third World. Social Science and Medicine, 36, 125-135. http://dx.doi.org/10.1016/0277-9536(93)90204-H

Chen, J. (2009). The Long-Term Trends of Marriage Rate, Divorce Rate, and Married Rate in Taiwan: Structural Determinants of Diversity in Marital Status in the Second Demographic Transition. Hong Kong Journal of Social Sciences, 26, 91120.

Chen, J. (2012). Does Global Fertility and Cultural Transition Affect Human Development? The Neglected Role of the Demographic Transition. Social Indicators Research, 113, 941-971. http://dx.doi.org/10.1007/s11205-012-0121-x

Clark, R., \& Filinson, R. (1991). Multinational Corporate Penetration, Industrialism, Region, and Social Security Expenditures: A Cross-National Analysis. International Journal of Aging and Human Development, 32, 143-159. http://dx.doi.org/10.2190/WFR2-TC6A-JX3L-F0QA

Crenshaw, E. (1992). Cross-National Determinants of Income Inequality: A Replication and Extension Using EcologicalEvolutionary Theory. Social Forces, 71, 339-363. http://dx.doi.org/10.1093/sf/71.2.339

Crenshaw, E., \& Ameen, A. Z. (1997). Population Dynamics and Economic Development: Age-Specific Population Growth Rates and Economic Growth in Developing Countries, 1965 to 1990. American Sociological Review, 62, 974-984. http://dx.doi.org/10.2307/2657351

CSDH (2008). Closing the Gap in a Generation: Health Equity through Action on the Social Determinants of Health. Final Report of the Commission on Social Determinants of Health, Geneva: World Health Organization.

Davey Smith, G. (1996). Income Inequality and Mortality: Why Are They Related? British Medical Journal, 312, 987-988. http://dx.doi.org/10.1136/bmj.312.7037.987

Dyson, T. (1989). India’s Historical Demography: Studies in Famine, Disease, and Society. London: Curzon.

Dyson, T. (2001). A Partial Theory of World Development: The Neglected Role of the Demographic Transition in the Shaping of Modern Society. International Journal of Population Geography, 7, 67-90. http://dx.doi.org/10.1002/ijpg.215

Dyson, T. (2011). The Role of the Demographic Transition in the Process of Urbanization. Population and Development Review, 37, 34-54. http://dx.doi.org/10.1111/j.1728-4457.2011.00377.x

Finkel, D. (1995). Causal Analysis with Panel Data. Newbury Park, CA: Sage Publications. http://dx.doi.org/10.4135/9781412983594

Firebaugh, G. (1992). Growth Effects of Foreign and Domestic Investment. American Journal of Sociology, 98, 105-130. http://dx.doi.org/10.1086/229970

Frank, D. J. (1997). Science, Nature, and the Globalization of the Environment, 1870-1990. Social Forces, 76, $409-437$. http://dx.doi.org/10.1093/sf/76.2.409

Frank, D. J., \& McEneaney, E. H. (1999). The Individualization of Society and the Liberalization of State Policies on SameSex Sexual Relations, 1984-1995. Social Forces, 77, 911-944. http://dx.doi.org/10.1093/sf/77.3.911

Halaby, C.N. (2004). Panel Models in Sociological Research: Theory into Practice. Annual Review of Sociology, 30, 507-544. http://dx.doi.org/10.1146/annurev.soc.30.012703.110629

Hall, P., \& Lamont, M. (2009). Successful Societies: How Institutions and Culture Affect Health. New York: Cambridge University Press. http://dx.doi.org/10.1017/CBO9780511816192

Hardin, G. (1993). Living Within Limits. Oxford: Oxford University Press.

Johnson-Hanks, J., Morgan, P., Bachrach, C., \& Kohler, H.-P. (2006). The American Family in a Theory of Conjunctural Action. http://www.soc.duke.edu/ efc/publications.php

Judge, K., Mulligan, J., \& Benzeval, M. (1998). Income Inequality and Population Health. Social Science and Medicine, 46, 567-579. http://dx.doi.org/10.1016/S0277-9536(97)00204-9

Kawachi, I., Kennedy, B. P., \& Wilkinson, R. G. (1999). Crime: Social Disorganization and Relative Deprivation. Social Science and Medicine, 48, 719-731. http://dx.doi.org/10.1016/S0277-9536(98)00400-6

Kentor, J. (1998).The Long-Term Effects of Foreign Investment Dependence on Economic Growth, 1940-1990. American Journal of Sociology, 103, 1024-1046. http://dx.doi.org/10.1086/231295

Kwon, T.-H. (2003). Demographic Trends and Their Social Implications. In D. C. Shin, C. P. Rutkowski, \& C.-M. Park (Eds.), The Quality of Life in Korea (pp. 19-38). Berlin: Springer. http://dx.doi.org/10.1007/978-94-017-0281-2 2

Lee, R., \& Mason, A. (2010). Fertility, Human Capital, and Economic Growth over the Demographic Transition. European Journal of Population, 26, 159-182. http://dx.doi.org/10.1007/s10680-009-9186-x

Lenski, G., \& Lenski, J. (1982). Human Societies (4th ed.). New York: McGraw-Hill.

Lenski, G., \& Nolan, P. D. (1984). Trajectories of Development: A Test of Ecological-Evolutionary Theory. Social Forces, 
63, 1-23. http://dx.doi.org/10.1093/sf/63.1.1

London, B. (1992). School-Enrollment Rates and Trends, Gender, and Gertility: A Cross-National Analysis. Sociology of Education, 65, 306-316. http://dx.doi.org/10.2307/2112773

Lynch, J., \& Smith, G. D. (2000). Income Inequality and Health: Expanding the Debate. Social Science and Medicine, 51, 1001-1005. http://dx.doi.org/10.1016/S0277-9536(00)00080-0

Lynch, J., Smith, G. D., Harper, S., Hillemeier, M., Roos, N., \& Kaplan, G. A. (2004). Is Income Inequality a Determinant of Population Health? Part 1. A Systematic Review. The Milbank Quarterly, 82, 5-99.

Mackenbach, J. (2002). Income Inequality and Population Health. British Medical Journal, 324, 1-2. http://dx.doi.org/10.1136/bmj.324.7328.1

McNay, K. (1995). Fertility and Frailty: Demographic Change and Health and Status of Indian Women. Economic and Political Weekly, 30, 81-86.

Mellor, J. M., \& Milyo, J. (2001). Reexamining the Evidence of an Ecological Association between Income Inequality and Health. Journal of Health Politics, Policy and Law, 26, 487-522. http://dx.doi.org/10.1215/03616878-26-3-487

Messner, S. F. (1989). Economic Discrimination and Societal Homicide Rates: Further Evidence on the Cost of Inequality. American Sociological Review, 54, 597-611. http://dx.doi.org/10.2307/2095881

Meyer, J., Boli, J., Thomas, G., \& Ramirez, F. (1997). World Society and the Nation-State. American Journal of Sociology, 103, 144-181. http://dx.doi.org/10.1086/231174

Moore, W. E. (1966). Social Change. Upper Saddle River, NJ: Prentice-Hall.

Muller, E. N. (1995). Economic Determinants of Democracy. American Sociological Review, 60, 966-982. http://dx.doi.org/10.2307/2096435

Murdoch, W. W. (1980). The Poverty of Nations. Baltimore, MD: Johns Hopkins University Press.

Murphy, M. (2011). Long-Term Effects of the Demographic Transition on Family and Kinship Networks in Britain. Population and Development Review, 37, 55-80. http://dx.doi.org/10.1111/j.1728-4457.2011.00378.x

Myers, N., \& Simon, J. L. (1994). Scarcity or Abundance: A Debate on the Environment. New York: W.W. Norton.

Nielsen, F., \& Anderson, A. S. (1995). Income Inequality, Development, and Dualism: Results from an Unbalanced CrossNational Panel. American Sociological Review, 60, 674-701. http://dx.doi.org/10.2307/2096317

Omran, A. R. (1971). The Epidemiologic Transition: A theory of the Epidemiology of Population Change. The Milbank Memorial Fund Quarterly, 49, 509-538. http://dx.doi.org/10.2307/3349375

Parsons, T. (1966). Societies: Evolutionary and Comparative Perspectives. Upper Saddle River, NJ: Prentice-Hall.

Pop, I. A., Ingen, E. V., \& Oorschot, W. V. (2012). Inequality, Wealth and Health: Is Decreasing Income Inequality the Key to Create Healthier Societies? Social Indicator Research, 113, 1025-1043.

Ram, R. (2006). Further Examination of the Cross-Country Association between Income Inequality and Population Health. Social Science and Medicine, 62, 779-791. http://dx.doi.org/10.1016/j.socscimed.2005.06.034

Reher, D. S. (2004). The Demographic Transition as a Global Process. Population, Space and Place, 10, 19-41. http://dx.doi.org/10.1002/psp.313

Reher, D. S. (2011). Economic and Social Implications of the Demographic Transition. Population and Development Review, 37, 11-33. http://dx.doi.org/10.1111/j.1728-4457.2011.00376.x

Rodgers, G. B. (1979). Income and Inequality as Determinants of Mortality: An International Cross-Section Analysis. Population Studies, 33, 343-351. http://dx.doi.org/10.1080/00324728.1979.10410449

Salomon, J. A., \& Murray, C. J. L. (2002). The Epidemiologic Transition Revisited: Compositional Models for Causes of Death by Age and Sex. Population and Development Review, 28, 205-228.

http://dx.doi.org/10.1111/j.1728-4457.2002.00205.x

Schafer, M. J. (1999). International Nongovernmental Organizations and Third World Education in 1990: A Cross-National Study. Sociology of Education, 72, 69-88. http://dx.doi.org/10.2307/2673177

Shandra, J. M., Restivo, M., Shircliff, E., \& London, B. (2011). Do Commercial Debt-for-Nature Swaps Matter for Forests? A Cross-National Test of World Polity Theory. Sociological Forum, 26, 381-410. http://dx.doi.org/10.1111/j.1573-7861.2011.01245.x

Shannon, T. R. (1989). An Introduction to the World-System Perspective. Boulder, CO: Westview.

Shen, C., \& Williamson, J. B. (1999). Maternal Mortality, Women’s Status, and Economic Dependency in Less Developed Countries: A Cross-National Analysis. Social Science and Medicine, 49, 197-214.

http://dx.doi.org/10.1016/S0277-9536(99)00112-4

Shircliff, E. J., \& Shandra, J. M. (2011). Non-Governmental Organizations, Democracy, and HIV Prevalence: A Cross-Na- 
tional Analysis. Sociological Inquiry, 81, 143-173. http://dx.doi.org/10.1111/j.1475-682X.2011.00366.x

Simpson, M. (1990). Political Rights and Income Inequality: A Cross-National Test. American Sociological Review, 55, 682693. http://dx.doi.org/10.2307/2095864

Solt, F. (2009). Standardizing the World Income Inequality Database. Social Science Quarterly, 90, 231-242. http://dx.doi.org/10.1111/j.1540-6237.2009.00614.x

Strang, D., \& Meyer, J. W. (1993). Institutional Conditions for Diffusion. Theory and Society, 22, 487-511. http://dx.doi.org/10.1007/BF00993595

Summers, R., \& Heston, A. (1984). Improved International Comparisons of Real Product and Its Composition: 1950-1980. Review of Income and Wealth, 30, 207-262. http://dx.doi.org/10.1111/j.1475-4991.1984.tb00486.x

Tausch, A. (2012). A Globalization-Oriented Perspective on Health, Inequality, and Socio-Economic Development. International Journal of Health Planning Management, 27, 2-33. http://dx.doi.org/10.1002/hpm.1090

Taylor, C. L., \& Hudson, M. C. (1979). World Handbook of Political and Social Indicators (2nd ed.). New Haven, CT: Yale University Press.

Taylor, C. L., \& Jodice, D. A. (1983). World Handbook of Political and Social Indicators (3rd ed.). New Haven, CT: Yale University Press.

Van Bavel, J. (2006). The Effect of Fertility Limitation on Intergenerational Social Mobility: The Quality-Quantity TradeOff during the Demographic Transition. Journal of Biosocial Science, 38, 553-569. http://dx.doi.org/10.1017/S0021932005026994

Walsh, J. A., \& Warren, K. S. (1979). Selective Primary Health Care: An Interim Strategy for Disease Control in Developing Countries. The New England Journal of Medicine, 301, 967-974. http://dx.doi.org/10.1056/NEJM197911013011804

Wickrama, K. A. S., \& Lorenz, F. O. (2002). Women’s Status, Fertility Decline, and Women’s Health in Developing Countries: Direct and Indirect Influences of Social Status on Health. Rural Sociology, 67, 255-277.

http://dx.doi.org/10.1111/j.1549-0831.2002.tb00103.x

Wilkinson, R. G. (1992). Income Distribution and Life Expectancy. British Medical Journal, 304, 165-168. http://dx.doi.org/10.1136/bmj.304.6820.165

Wilkinson, R., \& Pickett, K. E. (2006). Income Inequality and Population Heath: A Review and Explanation of the Evidence. Social Science and Medicine, 62, 1768-1784. http://dx.doi.org/10.1016/j.socscimed.2005.08.036

Wimberley, D. (1990). Investment Dependence and Alternative Explanations of Third World Mortality: A Cross-National Study. American Sociological Review, 55, 75-91. http://dx.doi.org/10.2307/2095704 